\title{
Study on Application of Multimedia Technology in Teaching Ideological and Political Theories Course of Universities
}

\author{
Wang chong ${ }^{1}$ \\ ${ }^{1}$ Pingdingshan Institute of Education, Pingdingshan, Henan, 467000
}

Key Words: multimedia technology; ideological and political theories course of universities; application

\begin{abstract}
At the information age, multimedia has been used in many aspects of daily life, including the teaching of ideological and political theories course in universities. It helps to stimulate students' initiatives and to convert teachers' teaching techniques. However, some problems appear in such an application, such as teachers' over-dependence on multimedia, inappropriately handling tremendous and complex information, improper recognition of multimedia and unclear target of multimedia teaching. Therefore, the multimedia teaching needs to be promoted by combining with teaching goals, contents and other teaching techniques so as to improve education quality of ideological and political theories course of universities.Ideological and political theories course of universities aims to educate students with ideological and political theories and Marxism, and contributes to build correct outlooks on life, world and value of students. The teaching methods must be modified for the purpose of advancement of this course. And multimedia teaching refers to make classes more lively and active by processing words, pictures and videos in order to encourage students' initiatives for learning.
\end{abstract}

\section{Multimedia' Role in the Teaching of Ideological and Political Theories Course of Universities}

Characterized by interaction and integration, multimedia offers technical support for creating an active class environment by making teaching content more vivid and visual. It decreases students' learning difficulties and helps them to absorb and digest related knowledge, which means that it plays a very important role in cultivation of students' understanding and practices. How multimedia works in teaching ideological and political theories is shown as following:

It is said that interest is the beginning of success. For students, the improvement of teaching effects largely relies on their interests in ideological and political theories. Their interests are directly associated with grades and teachers' teaching goals. Traditionally, students learn from teachers' instruction about abstract theories. It may be uneasy for students to understand, and if students cannot understand or think this course boring, their interest will lose soon and thus increasing teachers' teaching difficulties. However, multimedia breaks such boring class modes by transforming tedious theories into vivid pictures, songs and videos, which actually arouse students' interests and attention. In addition, it frees teachers from blackboard writing and provides more opportunities for teacher-student interaction. At this point, students will have higher participation and much more learning initiatives.

The reform of ideological and political theories course has greatly changed teachers' role, not only as a knowledge initiator, but as a designer, guider and organizer of ideological and political theories course ${ }^{[1]}$. The advancement of course reform needs teachers to adjust their instilling teaching methods. For ideological and political theories course, teachers should substitute the 
traditional modes of introducing and listening with heuristic modes, and let students be involved and be the master of classes. The interaction feature of multimedia teaching greatly arouses students' desire to involve in classes in which they not only obtain the knowledge, but practice their capabilities of operation and thinking. For example, the problems situation of multimedia teaching increases interaction between teachers and students, enriches teaching content, arouses students' initiatives and modifies their learning approaches. Its application breaks empty, dull teaching environment with creating a multi-dimensional and dynamic learning and teaching atmosphere, in which students consistently immerse themselves into a positive, active, practical and cooperative learning mode.

Curriculum reform of universities requires and aims at promoting teaching effects of ideological and political theories course. With employing multimedia, much more knowledge and information will presented during same class hours. It is totally different from traditional teaching mode, which requires teachers to do blackboard writing and explaining the textbook at the same time. Such a time- and energy-consuming way does not meet the needs of curriculum reform. But multimedia teaching corrects its imperfections by utilizing videos, pictures and other materials. And teachers can know current events from the multimedia so as to combine it with theories timely. It enriches teaching content, and frees teachers from repeated and boring works. Besides, multimedia teaching makes dull theories live and interesting by simplifying complex and difficult knowledge, which is useful for students to grasp and understand. In that way, students are more interested in learning ideological and political theories course, and thus achieving the goals of curriculum reform.

\section{Problems of Multimedia Technology in Teaching Ideological and Political Theories Course of Universities}

Every coin has two sides, so does multimedia technology. As important it is in teaching ideological and political theories course of universities, some problems cannot be ignored and wait to be solved. They are shown as following.

Multimedia teaching requires organic combination of multimedia technology and teaching goals, content and methods, instead of simple addition of the technology and the course ${ }^{[3]}$. Some teachers think that multimedia teaching is to teaching with computer courseware. In fact, it is only one part of lessons preparation. Teachers should organically combine materials and teach interactively and directly based on teaching principles and requirements. Meanwhile, there also are problems in making and using coursewares since teachers download and buy them indiscriminately. These coursewares are not targeted and thus lower teaching qualities. And teachers cannot take full advantage of multimedia functions as a result of their incapability of mastering multimedia technology.

The ideological and political theories course of universities intends to guide students to think positively and build proper outlooks on life, world and values. However, some teachers pay much attention on information transferring and course progress, and regard ideological and political theories course as video and pictures presentation, which go against the nature of classes teaching to some extent that essentially is information exchanging process and teacher-student interaction. In addition, the pursuit of information will cause students negatively receive too much things without understanding and thinking. At the same time, under the environment full of videos and pictures, students have difficulties in forming a systematic and complete line of knowledge which harms their future development. That is to say, too much information makes teaching goals unclear and weakens students’ dominant position, and hence adversely affecting teaching quality.

Multimedia teaching is rigorous and tight. If teachers rely on multimedia too much and teach 
strictly according to it, the interaction between teachers and students will be reduced greatly ${ }^{[5]}$, which is the biggest disadvantage of present multimedia teaching. Teachers spend most time on the platform so that they can control the multimedia presentation. In this case, teachers have no time to notice students' response and acceptability for their introduction. As a result, the classes become boring and dull, and students are less actively involved in the classes.

\section{Application Strategies of Multimedia Technology in Teaching Ideological and Political Theories Course of Universities}

Based the above mentioned advantages and disadvantages of multimedia teaching, the works need to be done from the following aspects to improve the teaching effects with multimedia.

During teaching ideological and political theories with multimedia, teachers should recognize that multimedia only functions as a tool and serves for teaching contents, as well as is controlled by

them ${ }^{[6]}$. So they must select appropriate content for presentation by combining courseware making with the textbook, and cannot copy mechanically. Furthermore, the coursewares should be heuristic, and students should be left enough time to think. Everything not connecting with teaching needs to disappear, like videos or images. Multimedia is a tool, not a panacea.

Multimedia is one kind of information technology employed in teaching activity, which obviously is of advantages and disadvantages. Therefore, teachers need to comprehensively utilize different teaching methods and make full use of their own advantages. They cannot rely on multimedia, nor reject it, but combine it with other techniques to maximize teaching effects.

Teachers are dominant in teaching process by playing guider and organizer roles while students are the master of learning. And multimedia is information exchanging media. The relationship between the three must be handled properly. In other words, the application of multimedia does not weaken or change teachers and students' role in learning. In whole multimedia teaching process, teachers make courseware appropriately by controlling the information volume and teaching pace. They also interact with students effectively in the forms of action, language and facial expression and so on ${ }^{[7]}$.

Many problems in multimedia teaching are associated with teachers' abilities to use this technology. On the one hand, since multimedia teaching is newly-rising mode, teachers are not familiar and lack practices and experiences, which lead to mechanical copy in teaching. And students' initiatives are reduced greatly ${ }^{[8]}$. On the other hand, universities' teachers are not instructed effectively with respect to multimedia teaching, but utilize based on their own experiences. However, this novel teaching mode is different from traditional teaching. For that reason, universities can organize some professional training and invite experienced teachers in multimedia teaching to give instruction to improve teachers' abilities. Meanwhile, teachers of ideological and political theories course can learn from others by watching related educational videos, and communicate with teachers from other universities for information exchanging ${ }^{[9]}$. To sum up, teachers should improve their own abilities to utilize multimedia technology. For example, in "Why China does not take capitalist road?", teachers can build a systematic table as following by multimedia for students’ better understanding. 


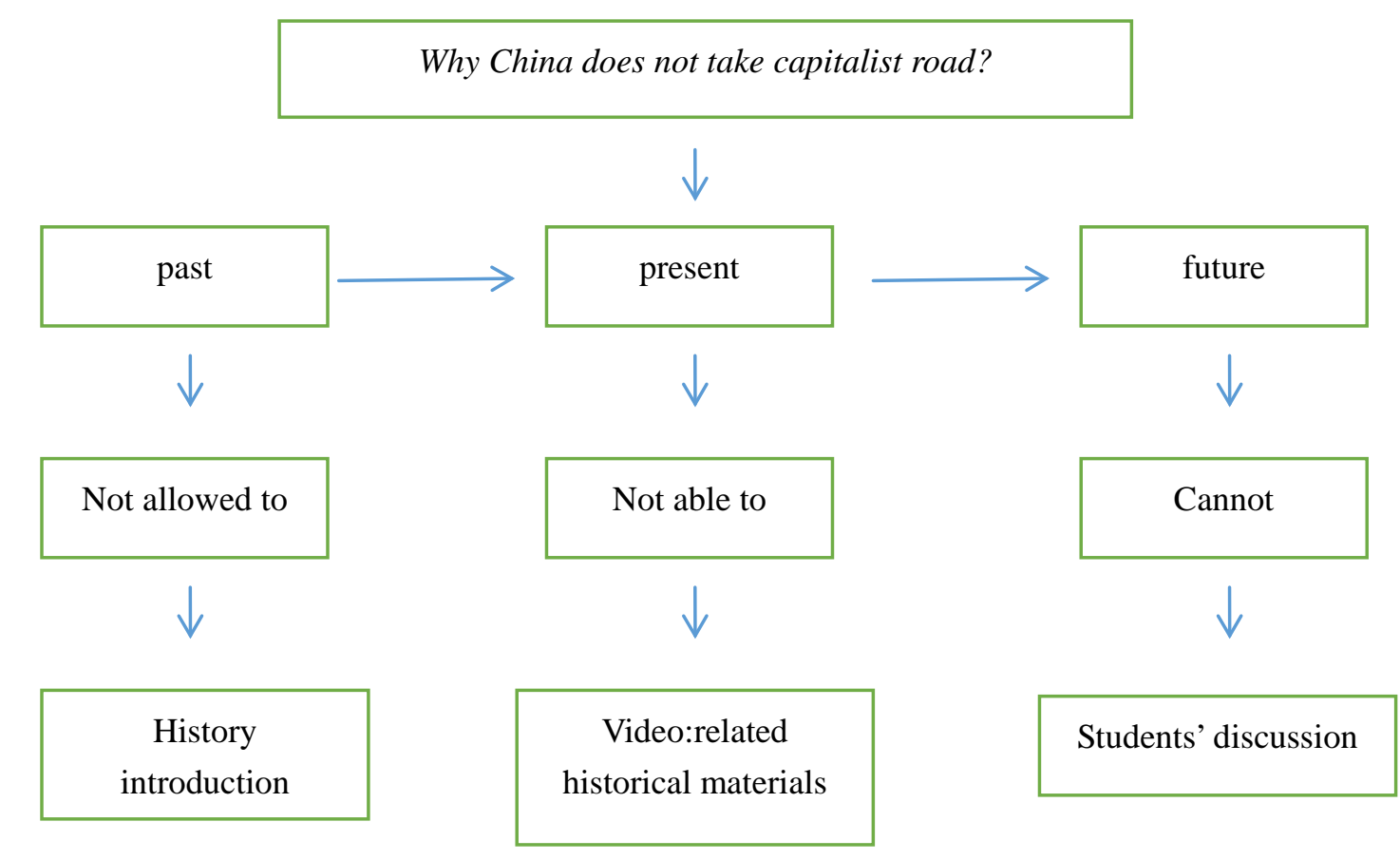

\section{Conclusion}

Since ideological and political theories course helps students to build a proper outlook on life, world and values, the nation and universities pay much attention on the organization and implementation of such course. And multimedia technology brings convenience for its education, as well as some troubles. Therefore, teachers need deal with the relationships between multimedia teaching mode and other teaching modes, and between themselves and students. They should promote their abilities to utilize multimedia, and thus making progresses in teaching qualities of ideological political theories course.

\section{References}

[1] Jin Yujun. Application of multimedia Technology in Ideological and Political Theories Course of Universities[J]. E-education Research, 2010(03).

[2] Li Ziyuan. Situation and Solutions of Multimedia Teaching of Ideological and Political Theories Course of Universities in Hu Bei province[J]. Journal of Ideological Theoretical Education, 2011(03).

[3] Miao Zhijuan, Pu Lixia. Researches on Design Innovation of Multimedia Teaching of Ideological and Political Theories Course of Universities-Taking Mao Zedong Thought and Introduction to the Theoretical System of Socialism with Chinese Characteristics as an Example[J]. Science and Technology of West China, 2014(01).

[4] Xiong Xiaowei. Factors and Solutions to Obstacles of Multimedia Teaching of Ideological and Political Theories Course of Universities[J]. Journal of Zhongzhou University, 2013(04).

[5] Chen Suhong. Correct Application of Multimedia Teaching in Ideological and Political Theories Course of Universities[J]. Theory and Practice of Contemporary Education, 2011(12).

[6] Li Jia. Multi-directional Interaction of Ideological and Political Theories Course of Universities based on Multimedia[J]. Journal of Nanchang College of Education, 2013(10).

[7] Zhu Dexin. Exploring and Implementing on Multimedia Interactive Teaching Mode of Ideological and Political Theories Course of Universities[J]. Journal of Hubei University of Economics, 2014(03). 
[8] Yang Songju. Construction of New Teaching Mode of Ideological and Political Theories Course of Universities - the Application of Modern Teaching Technology in Ideological and Political Theories Course [J]. Theory and Practice of Contemporary Education, 2011(04).

[9] Li Liang. Researches on Mode Design and Application of "Transferring and Receiving” based on Media-Exploring the Effects of Integrable Ware in Ideological and Political Theories Course of Universities[J]. Journal of Ideological Theoretical Education, 2010(02).

[10] Zhang Wenming. Ideological and Political Theories Course of Universities based on New Media Technology - Taking Multimedia Technology and Website of Ideological and Political Theories Education Department[J]. Journal of Tongren College, 2010(02). 